ISSN No. 0974-035X

An indexed refereed \& peer-reviewed journal of higher education

Towards Excellence

UGC-HUMAN RESOURCE DEVELOPMENT CENTRE

Gujarat University, Ahmedabad-380009, Gujarat, India

\title{
ROLE OF LIBRARIES IN ARCHITECTURAL EDUCATION IN INDIA
}

\author{
Dr. Priyanki Vyas \\ Ms. Daxa G. Patel
}

\begin{abstract}
:
The aim of this research is to study the role libraries in architecture education in India. The paper discusses about higher education, technical education, architecture education in India. Government of India has constituted some councils like AICTE, CoA \& NATA to planned quantitative growth, and regulation \& proper maintenance of norms and standards in the technical education system of architecture education. The role of libraries in research, literature search and access to information services in higher \& technical education has proved to be very important. This is challenging for libraries \& library professional to provide resources \& services as per the norms of AICTE \& CoA.

In this paper researcher focuses role of libraries \& library professionals in architecture education and also explains about library resources \& services which can provided to the user communities in architecture education.
\end{abstract}

Keywords: Architecture Education, Libraries, Library Resources, Library Services

\section{Introduction}

Education is very important in every aspect of human life. Due to development in Information Communication \& Technology (ICT) everything is moving and changing so rapidly. ICT has reshaped every activity of today's environment it includes business, education, military, transportation, communication, scientific investigation, knowledge management, etc.

In this environment education systems, methods and syllabi are drastically changed. Higher education is becoming a major driver of economic competitiveness in an increasingly knowledge - driven global 
economy. Government of India has given top priority of technical education in new education policy of India. Technical education has educated skilled manpower in human resource development of the country. Libraries and Information Service centers are knowledge hub and service provider of their institute or organization. They are playing an important role in widen support for the teaching-learning process, research and development and other academic activities.

\section{Higher Education in India}

Every education begins from school education which is contains primary education, secondary education and higher education. Higher education is an educational stage which is offered at colleges, universities, institute of technology, vocational institutes, career colleges etc.

The structure of higher education in India follows three main levels. These levels are bachelor /undergraduate level, master/ postgraduate level, and doctoral/ pre-doctoral level. All higher education courses are offered in various subjects. Bachelor Degree courses in all areas are offered to those students who have passed 12th level exam from a recognized board or university and three to five years of education. Master Degree or post graduate degree courses are usually two years of education except for some professional courses. Master Degree courses are offered to those students who qualified Bachelor Degree or undergraduate courses. Doctoral Degree $(\mathrm{PhD})$ is three years of study after Master degree.

\section{Technical Education in India}

Normally, there are two types of education at higher education level-general and technical. Technical education is something different from general education. Technical education is a part of education, in manufacturing and service industries It is directly related to the acquisition of necessary information and skills. Technical education covers every aspect of life and society. Since independence, the technical education system in India has developed to a great extent. Certificate, Diploma, Degree, Higher Degree and Doctorate in Institutions across the country opportunities is to provide education and training in a variety of professions and disciplines.

Technical Education plays a vital role in human resource development of the country by creating skilled manpower, enhancing industrial productivity and improving the quality of life of its people. Technical 
Education covers programmers in engineering, technology, management, architecture, town planning, pharmacy, applied arts \& crafts, hotel management and catering technology.

\section{Architectural Education in India}

At present, the construction sector is booming in Indian cities. Against this the demand for wealth has also increased with the increase in population. Now even high-rise buildings have become commonplace in the city, occupying very large spaces. Modern architecture has adapted to the environment and climate. Due to the changing economic situation in India in recent years as well as the construction industry has undergone a major change.

Architects design buildings for public or private use, including homes, sports complexes, schools, museums and convention centers. Their duties begin at the initial planning stages of a project and may include conceptual development of the structure, budget planning, supervision of the construction process and acquisition of building permits. Throughout the design and development of a building project, architects apply their knowledge of engineering, construction, materials and cost control.

Architectural Engineering is the one of the most important technical course in the global era of education. As compared to other professionals, architects are more capable of fitting into places because of their skill sets and their characteristics as problem solvers. Architecture students go through a rigorous training process in various fields, which helps them analyze their true potential and calling. (Saxena, 2021)

Under the provisions of the Architects Act, 1972 the Council of Architecture is required to prescribe the Minimum Standards of Architectural Education for imparting 5-year undergraduate degree course in Architecture (i.e. Bachelor of Architecture degree course) and also monitor the compliance of the same by the approved Architectural Institutions all over the country for award of recognized qualifications under the Act. (CoA, 2021).

There are about 573 institutions in India, which are imparting undergraduate degree course in Architecture leading to recognized qualifications. The standards of Education being imparted in these institutions (constituent colleges/departments of universities, deemed universities, affiliated colleges/schools, IITs, NITs and autonomous institutions) is governed by Council of Architecture. (CoA, 2021). 


\section{Council's for architectures education}

- AICTE

The AICTE Act was constituted to provide for the establishment of an All India Council for Technical Education with a view to proper planning and coordinated development of a technical education system throughout the country, the promotion of qualitative improvements of such education in relation to planned quantitative growth, and regulation \& proper maintenance of norms and standards in the technical education system and for the matters connected therewith. (AICTE, 2021)

\section{- CoA}

The Council of Architecture (COA) has been constituted by the Government of India under the provisions of the Architects Act, 1972. The Act provides for registration of Architects, standards of education, recognized qualifications and standards of practice to be complied with by the practicing architects. The Council of Architecture is charged with the responsibility to regulate the education and practice of profession throughout India besides maintaining the register of architects. For this purpose, the Government of India has framed Rules and Council of Architecture has framed Regulations as provided for in the Architects Act, with the approval of Government of India. (CoA, 2021)

- NATA- National Aptitude Test in Architecture

The purpose of conducting NATA is to provide a single scheme of examination for holding aptitude test and to facilitate prospective students all over the country to apply for admissions in architecture seats in institutions spread across the country. The NATA also ensures that the eligibility criteria for admission to five-year Bachelor of Architecture (B.Arch.) degree course, as prescribed by CoA.

\section{Resources of the College Libraries:}

The role of libraries in research, literature search and access to information services in higher \& technical education has proved to be very important. This is challenging for libraries \& library professional to provide resources \& services as per the norms of AICTE \& CoA.

\section{Required minimum Library Resources in architectural colleges as per the CoA Norms:}


- If it is 40 intakes in college, minimum collection of books should be a 300 volumes $\& 100$ titles, and adding in every year 150 volumes \& 50 titles.

- Print Journals with 2 International, \& 8 National.

- E-books \& E-journals PCs for access the library e-resources

\section{Requirements of Books \& Journals as per AICTE Norms}

- Minimum collection of books should be a 500 volumes \& 100 titles, and adding in every year 500 volumes \& 50 titles.

- Reading Capacity: $15 \%$ of the intakes

- E-Books \& E-Journals

The expected resources in the Architecture college libraries are broadly classified as printed and non-printed material. Printed resources include textbook, reference book, encyclopedia, dictionary, handbook, yearbook, manuals, bibliographic, reports, thesis, geographical tools, gazette's, atlases, journals, photographs. Non printed resources include microfilms, microfiche, micro card, filmstrips and recordings.

\section{Learning Resources in Architecture Education}

Some of the following are the useful learning resources in Architecture education.

\section{Online Databases of the architectures}

1. EBSCO OnArchitecture

2. GALE CENGAGE LEARNING:

3. ARTstor:

4. ArchDaily

\section{Open Access Resources}

1. AA School of Architecture - Projects Review

Projects Review is the culmination of the year's work at the Architectural Association, showcasing student work from across the school

2. AA School of Architecture - Lectures

A comprehensive list of AA London lectures videos

3. Architecture and Design Courses

A dedicated collection of architecture and design courses and tutorials for architects, students, designers, and people interested in learning about architecture. 


\section{Some useful Print Resources:}

- Encyclopedia of Architecture: Design engineering \&construction.

- Encyclopedia of 20th - century Architecture

- The architecture Handbook

- Handbook of Architectural Theory

- Dictionary of Architecture and Landscape Architecture (2nd)

\section{Library Facilities \& Services in Architecture Education}

Following facilities \& services can be providing to the Architecture Libraries

\section{Library Facilities}

- Online public access catalogue

- Reading room facility

- Scanning \& printing facility

- Photocopying facility

\section{Library Services}

Following services are offered by the CEPT library:

- Circulation

- Article index of selected periodicals.

- Compilation of specialized bibliographies on demand.

- New arrivals.

- Inter Library Loan Services.

- Library orientation to fresh members.

- Current awareness service to faculty members

- Exhibitions at the library

\section{Conclusion:}

Architecture Education is very diverse, which can open up a wide array of career paths for students. In it, library plays vital role in academic activities and provides core support to teaching, learning, scholarship and in research. To keep update, the architectural students, research scholars and faculties with the latest technology trends of new equipment, information products, searching, dissemination, and make them aware of the usage on authentic information in legal and ethical manner. Library and library professionals can provide learning resources $\&$ facilities to meet the need of architecture education communities. 


\title{
References
}

- AICTE. https://www.aicte-india.org/ accessed on 20-1-2021

- CoA. https://www.coa.gov.in accessed on 21-1-2021

- Higher Education. https://www.essaysauce.com/education-essays/higher-education-india/

- Library. https://cept.ac.in/library. accessed on 21-1-2021

- Saxena, Ojaswita. Rethinking architectural education- Emphasizing on different career paths https:/www.re-thinkingthefuture.com/fresh-perspectives/a1783-rethinking-architectural$\underline{\text { education-emphasizing-on-different-career-paths/accessed on 18-1-2021 }}$

- Technical Education. https://www.mhrd.gov.in/en/technical-education-hi Access on 13-1-2021

- Technical Education. https://www.education.gov.in/en/technical-education

- Technical Education. https://www.yourarticlelibrary.com/education/objectives-of-technicaleducation-in-india/45181

\author{
Dr. Priyanki Vyas \\ Head \& Associate Professor \\ Department of Library and Information Science
}

Dr. Babasaheb Ambedkar Open University (BAOU),Ahmedabad

Mobile Number : 9408778536, E-mail : priyanki.vyas@baou.edu.in

\&

Ms. Daxa G. Patel

Research Scholar

Department of Library and Information Science

Dr. Babasaheb Ambedkar Open University (BAOU), Ahmedabad

Mobile Number : 9924010826, E-mail : daxa2407@gmail.com 